\title{
Devising and Testing Revised Validity and Reliability of Strategic Knowledge, Efficient Behaviour, and Affective Value in Outdoor Evaluation Questionnaire
}

\author{
Alvin Raj Santhanadass ${ }^{1}$, Gunathevan Elumalai ${ }^{2}$, Yudik Prasetyo ${ }^{3}$, Jaffry Zakaria ${ }^{4}$ \\ \{alvin_rajj@yahoo.com ${ }^{1}$, gunathevan@fsskj.upsi.edu.my ${ }^{2}$, yudik@uny.ac.id ${ }^{3}$, \\ jaffry@fsskj.upsi.edu.my $\left.{ }^{4}\right\}$ \\ Universiti Pendidikan Sultan Idris, Malaysia ${ }^{1,2,4}$ \\ Universitas Negeri Yogyakarta, Indonesia ${ }^{3}$
}

\begin{abstract}
This research aims to obtain revised validity and reliability of an outdoor survey instrument to self-evaluate strategic knowledge, efficient behaviour, and affective value among students aged 13-17 years. The researchers used six survey evaluation, namely the Tennessee Self Concept Questionnaire, Multifactor Leadership Questionnaire (MLQ), Participant Motivation Questionnaire (PMQ), Cooper Smith Inventory, Group Environment Questionnaire (GEQ), and Outdoor Education Manual (MPL) to develop an outdoor self-evaluation questionnaire on strategic knowledge, efficient behaviour, and affective value (SKEBAV). The Development of the survey instrument involved 120 male and female research samples aged between 13 and 17 years old who were selected through purposive random sampling. The research method applied is in the form of pre-experimental one group pre-test-post-test design. Results of the analysis showed that overall activity expert validity is $r=.90$ and language expert validity is $r=.93$, while the Cronbach alpha reliability correlation value of outdoor education instrument evaluation survey is $r=.90$. Next, this survey was tested again for construct validity using factor analysis method for statistical analysis where it validates each item to be either correctly evaluated according to the components or not. Analysis results showed that Bartlett's test is significant at $\mathrm{p}<.05$ and Kaiser-Meyer-Olkin index range is $r=.80$. A variant of 90.16 percent is explained from 18 components which were analysed with more than one eigenvalue. A total of 50 survey items were produced out of the survey's 100 items based on this factor analysis method. Research has shown that the survey instrument developed is valid and reliable to be used for Sabah's Co-curricular Camping activities.
\end{abstract}

Keywords- Validity, Reliability, Strategic knowledge, Efficient Behaviour and Affective

\section{Introduction}

Outdoor Education is an individual's transformation process that involves his or her knowledge, skills, or behavior due to experience [1]. Outdoor Education has the capability to liven up its curriculum scene, where it links theory and reality in a natural environment. It helps students to comprehend the environment better in addition to stimulating the physical activities in Outdoor Education.

Apart from that, Outdoor Education assists the development of cognitive, affective, and psychomotor values on top of an individual's social values whenever Outdoor Education learning is being applied [2]. It is a unique education niche due to its amalgamation of the teaching process with learning that is based on theory and practice carried out in a natural 
environment, or the nature. The usual activities in Outdoor Education includes camping, kayaking, orienteering, flying fox, wall climbing, rock climbing, learning adventure, mountain climbing, cycling, start aid and many more [3].

Outdoor Education philosophy describes nature as a living laboratory abundant with the sources of knowledge. It can be intertwined with practices that could enrich experience and nurtures fine values that would give birth to an individual that is mentally, spiritually, and physically sound, in a bid to foster integration among the society and create national unity [4]. It is a common consensus that in Malaysian schools, Outdoor Education program scope spans over the knowledge of nature and the development of positive outlook towards it. Outdoor Education can develop moderation in self-efficacy in addition to enhancing the leadership quality in an individual and the society. This program also serves as the finishing touches to academic knowledge in a real or realistic situation and employs the behavioral efficiency skills when interacting with the nature frequently [5].

In line with the National Education Philosophy, the Malaysian Ministry of Education has established co-curriculum centers in each state as a concept hoped to promote Outdoor Education to students. These state co-curriculum centers aim to provide learning experience through real life activities, in addition to emphasizing enhancement in knowledge, skills, discipline, self-confidence, and fine value fortifications that could lead to an individual's excellence [6].

The co-curriculum center serves as an Outdoor Education institution that organize activities involving core curriculum and elective curriculum. Core curriculum are curriculums compulsory in each program. In contrast, elective curriculum comprises of religious and moral education, patriotism, motivation, nature education, start aid and social services. Land activities, air activities, and high-risk activities are the choices of activities available in Outdoor Education. Land activities primarily involves activities like camping craft, orienteering, survival, cycling, mountain climbing, obstacle clearing and marching. On the other hand, water activities included self-confidence and water safety activities, swimming, kayaking, rafting, tubing, and snorkeling. High-risk activities are classified as activities such as wall climbing, flying fox, repelling and rope skills [6].

The Outdoor Education program organized by Sabah State Co-curriculum Center is rapidly gaining favorable response from schools in Sabah. The organized program was found to have a positive impact on motivation, group unity, self-efficacy, and human development [6]. However, the 2012 Annual Sabah Co-curriculum Center report did not present the strategic knowledge, efficient behavior and participant's affective aspect using a validated, reliable, systematic, and consistent instrument when assessing the participants of Outdoor Education program in this center.

Consistent testing, measurement, and evaluation plays an imperative role in ensuring the achievement of Outdoor Education objectives. Method of assessment is an integration of information gathering, information interpretation or evaluating the procured information, and decision making [7]. Curated information based on outdoor education study should be systematic and orderly to ensure an assessment could be conducted. An Outdoor Education instrument that consisted of consistent testing, measuring, and assessment can be used to test and collect information or data for a study. An assessment had to be conducted to determine an individual's achievement in Outdoor Education. To fulfill the objectives of an instrument, only the testing, measurement, and evaluation based on valid and reliable assessment instruments can accurately analyze the data [8].

Validity and reliability instruments are pivotal in ensuring instrument accuracy against errors. The higher the value and degree of validity and reliability of an instrument, the more 
accurate the data obtained for creating a good and high-quality study in Outdoor Education is [9]. The validity and reliability of an instrument should closely follow the set criteria to ensure its capacity to measure, assess and evaluate correctly. To date, the only available validated and reliable education evaluation instrument for the measurement of strategic learning, behavior efficiency and affective for students aged 15 and 16 in Sabah co-curriculum center are international ones. Hence, this study aims to establish the validity and reliability of the Outdoor Education assessment instrument for secondary school students aged 13 to 17 .

In this study, the researchers employed Multiple Intelligence Theory [10] and True Score Theory [11], which are highly relevant to the study. The domains of strategic knowledge, behavior efficiency, and affective that were coupled with validity and reliability played a key role in developing an accurate and correct assessment instrument to test the Outdoor Education evaluation instrument [12-17]. Several appropriate test instruments were selected to be used in this study by the researchers, based on prior studies. Ahmad Hashim (2004) stated that an instrument or test to be used in the measurement and assessment of an information should have the characteristics of reliability, objectivity, and validity. Only tests boasting these features could provide an accurate measurement.

The objective of this research is to find the outdoor education camping instrument through several change factors that are related to the students who fully participated in the camping activity. To attain this goal, the researchers have underlined several research objectives such as determining the instrument validity based on activity experts and language experts, outdoor education instrument's reliability and validity of outdoor education instrument isolated construct.

\section{Methods}

This study strives to develop a questionnaire and establish the validity and reliability of an outdoor education evaluation instrument. To achieve this goal, a pre-experimental study by the method of one group pretest-posttest was performed. The experimental design for one group pretest-posttest method consisted of three steps [18]. First, administrating the pre-tests to measure dependent variable; second, treatment application or intervention to the subjects; and third, re-administration of post-tests to dependent variables. This study is divided into three parts, the first part being to obtain the validity of content and the validity of Language from appointed experts for the constructed instrument. The second part involves acquiring the reliability of constructed instrument post activity and the third part aims to get the construct validity via principal component analysis test to ensure each item in each three components truly represents the said components and did not deviate from the true component.

The researcher has adapted and changed several questionnaires and manual taken from other studies in order to develop the questionnaire specifically for the aspects of strategic knowledge, efficient behaviour and affective domain, similar to the survey on Tennessee selfconcept [19], multifactor leadership questionnaire [20]; participant motivation questionnaire [21] Cooper Smith inventory [22] and group environment questionnaire [23]. The Outdoor education manual [24] was used to develop a questionnaire for strategic knowledge and affective domains. This questionnaire was selected based on first, possessing high validity and reliability; second, successfully meeting the requirements of Gardner's Multiple Intelligence Theory and true score theory; third, the questionnaire items could fulfill the measurement aspect for strategic knowledge components, behavior efficiency and affective; and lastly, is suitable to use by 
students aged 13 and 17 of both genders. All questionnaires were tested using the five-point scale. A total of 100 items for the questionnaire were developed to be tested during the outdoor education camping. The amount of questionnaire items for strategic knowledge component is 25 , efficient behaviour has 25 items whilst affective was given 50 items.

For data collection, the researchers use SPSS version 17.00. The analysis used included field experts and language experts' validity analysis; to enable every item asked the ability to fulfil the criteria required and to focus on the right component. Next, Cronbach Alpha statistic was used to obtain reliability while isolated construct validity was used with factor analysis method. The extraction technique applied in this analysis was Principal Components Analysis. Orthogonal rotation factor which is the Varimax rotation method was also used. This factor analysis method was carried out according to three main steps. Firstly, it involves evaluating suitable data for factor analysis method. Secondly, the extraction factor, and thirdly, the application of rotation factor and interpretation [25]. To evaluate whether the data is suitable, the researchers had examined the correlation coefficient matrix values at 0.3 and above [26]. Bartlett's test (Bartlett's test of sphericity) was used to see whether the sample is sufficient. Factor analysis method would be suitable when the results from Bartlett's test is significant ( $p$ $<.05)$ and Kaiser-Meyer-Olkin $(K M O)$ index range is in between 0 to 1 , with $r=.3$ suggested as the minimum value for a good factor analysis [27]

\subsection{Sample Size and Subjects}

Table 1 depicted the sample size selection for this study, which was done according to Power Tables for Effect Size (ES) [28]. Past researchers agreed that sampling power value at .80 is reasonable and realistic for a behavioral science research [29]. The researchers used minimum size effect value (d) .50 for sample to lessen the degree of error effect. A significant level of $\alpha=.05$ was set by the researchers in this study. A total of 120 subjects will be used as study samples $(60=$ male, $60=$ female $)$, of whom will participate in outdoor education camping and are made up of students aged 13 to 17 years old from secondary schools of every district in Sabah. This is finalized after considering the possibilities of absence or mortality [18]. The students involved are individuals with basic knowledge of Outdoor Education activities. Following that, the researchers drafted sampling framework by using intact sampling strategy, which is also known as purposive sampling [30-31].

Table 1. Study Sample Size Based on Power and Effect Size

\begin{tabular}{|c|c|c|c|c|c|c|c|c|c|c|c|}
\hline \multicolumn{12}{|c|}{ ES Power $=.80$ for $\alpha=.05$ and .50} \\
\hline Power & .10 & .20 & .30 & .40 & .50 & .60 & .70 & .80 & 1.00 & 1.20 & 1.40 \\
\hline .25 & 332 & 84 & 38 & 22 & 14 & 10 & 8 & 6 & 5 & 4 & 3 \\
\hline .50 & 769 & 193 & 86 & 49 & 32 & 22 & 17 & 13 & 9 & 7 & 5 \\
\hline .60 & 981 & 246 & 110 & 62 & 40 & 28 & 21 & 16 & 11 & 8 & 6 \\
\hline $2 / 3$ & 1144 & 287 & 128 & 73 & 47 & 33 & 24 & 19 & 12 & 9 & 7 \\
\hline .70 & 1235 & 310 & 138 & 78 & 50 & 35 & 26 & 20 & 13 & 10 & 7 \\
\hline .75 & 1389 & 348 & 155 & 88 & 57 & 40 & 29 & 23 & 15 & 11 & 8 \\
\hline .80 & 1571 & 393 & 175 & 99 & 64 & 45 & 33 & 26 & 17 & 12 & 9 \\
\hline
\end{tabular}




\begin{tabular}{cccccccccccc}
.85 & 1797 & 450 & 201 & 113 & 73 & 51 & 38 & 29 & 19 & 14 & 10 \\
.90 & 2102 & 526 & 234 & 132 & 85 & 59 & 44 & 34 & 22 & 16 & 12 \\
.95 & 2600 & 651 & 290 & 163 & 105 & 73 & 54 & 42 & 27 & 19 & 14 \\
.99 & 3675 & 920 & 409 & 231 & 148 & 103 & 576 & 58 & 38 & 27 & 20 \\
\hline
\end{tabular}

\section{Results and Discussion}

Results from the analysis of activity expert correlation validity value for outdoor education survey instrument analysis are as follows: expert one is .85, expert two is .90 and expert three is .92 . As for the whole expert validity, it was at $r=.90$. According to Sidek and Jamaludin ${ }^{32}$ and Tuckman and Waheed ${ }^{33}$, the value $r=.70$ was considered as mastery or attainment of the highest achievement level. As for the analysis of language expert correlation validity value for outdoor education survey instrument, the details were as follows; language expert one, $r=.90$, language expert two, $r=.89$ and the third expert, $r=.91$. Total value of reliability for language expert validity was $r=.91$. In addition, total value of Cronbach Alpha for strategic knowledge component was $r=.89$, efficient behaviour $r=.88$, and affective $r=.90$.

The whole outdoor education survey instrument had the Cronbach Alpha correlation value of $r=.90$. This shows that the survey instrument that was adapted and developed can be used. However, factor analysis was still conducted to ensure that each item that was developed were able to test the right component and are non-repetitive. This research analysis showed that all questionnaire items in this study had correlation coefficient value of $r=.3$ and above. The KMO value obtained was $r=.80 .90 .16$ and Bartlett's test was significant $(p=.000)$, therefore factor analysis was deemed suitable to be used in the next test. Kaiser's criterion technique was used to determine the number of components. Components with only eigenvalue one or more were selected in this analysis. There were 18 analysis components which had more than one eigenvalue: all of these 18 analysis component explained 85.13 percent variance. Matrix component showed loading in each line and expressed each survey item's correlation with strategic knowledge, efficient behaviour, and affective domains. To maintain three components for the next analysis, the researchers used varimax rotation method to minimize the number of survey items that had high correlation on each factor. According to Tabachnick and Fidell, results based on orthogonal rotation was easier to translate and report.

Table 2 shows the results from the three components rotation using the varimax rotation method. Results showed that the first component explained 11.255 percent of variance, the second component explained 10.927 percent of variance, and the third component explain 10.544 percent variance. The total amount of variant available which could be explained by all three components was 66.16 percent variance and remain unchanged after rotation.

Table 2. Total Variance Explained (Extraction Method: Principal Component Analysis)

\begin{tabular}{ccrr}
\hline Component & \multicolumn{3}{c}{$\begin{array}{c}\text { Rotation Sums of Squared Loadings } \\
\text { Total } \% \text { of Variance }\end{array}$} \\
& Cumulative \% \\
\hline 1 & 10.692 & 11.255 & 11.255 \\
2 & 10.380 & 10.927 & 22.182 \\
3 & 10.016 & 10.544 & 32.726 \\
\hline
\end{tabular}

Based on Principal Component Analysis, from 100 survey items only 50 showed high communality score. Component line one represented the outdoor evaluation instrument which 
measures strategic knowledge, the second line represented outdoor evaluation instrument which measures affective domain, while the third line represented outdoor education evaluation instrument which measured efficient behaviour.

Table 3 shows a total of 50 items from 100 survey items that consisted of strategic knowledge, efficient behaviour and affective components were eliminated during the factor analysis processes. This was due to the loading factor being lower than .30 , with no relation between survey item and the component [34].

Table 3. Item before and after principal component analysis

\begin{tabular}{|c|c|c|}
\hline Component & $\begin{array}{l}\text { Item for Analysis Factor } \\
\text { (100 Items) }\end{array}$ & $\begin{array}{l}\text { Item selected after Analysis Factor } \\
\text { (50 items) }\end{array}$ \\
\hline Strategic knowledge & $\begin{array}{l}\text { S1, S2, S3, S4, S5, S6, S7, S8, S9, } \\
\text { S10 } \\
\text { S11, S12, S13, S14, S15, S16, S17, } \\
\text { S18, S19, S20, S21, S22, S23, S24, } \\
\text { S25 }\end{array}$ & $\begin{array}{l}\text { S9, S24, S11, S12, S13, S14, S15, } \\
\text { S16, S17, S18, S5, S2, S1, S3, S22, }\end{array}$ \\
\hline Efficient behavior & $\begin{array}{l}\text { S26, S27, S28, S29, S30, S31, S32, } \\
\text { S33, S34, S35, S36, S37, S38, S39, } \\
\text { S40, S41, S42, S43, S44, S45, S46 } \\
\text { S47, S48, S49, S50, }\end{array}$ & $\begin{array}{l}\text { S28, S30, S32, S33, S34, S35 S36, } \\
\text { S37, S38, S39, S42, S47, S48, S49, } \\
\text { S50 }\end{array}$ \\
\hline Affective value & $\begin{array}{l}\text { S51, S52, S53, S54, S55, S56, S57, } \\
\text { S58, S59, S60, S61, S62, S63, S64, } \\
\text { S65, S66, S67, S68, S69, S70, S71, } \\
\text { S72, S73, S74, S75, S76, S77, S78, } \\
\text { S79, S80, S81, S82, S83, S84, S85, } \\
\text { S86, S87, S88, S89, S90, S91, S92, } \\
\text { S93, S94, S95, S96, S97, S98, S99, } \\
\text { S100 }\end{array}$ & $\begin{array}{l}\text { S54, S55, S58, S60, S62, S64, S66, } \\
\text { S68, S69, S75, S76, S77, S81, S83, } \\
\text { S86, S88, S91, S93, S94, S95 }\end{array}$ \\
\hline
\end{tabular}

Selection for construct component for strategic knowledge, efficient behaviour and affective domain in this study was based on high main loading and it was found to exceed the correlation coefficient value $r=0.50$. This was caused by a high correlation value of a test on a measured factor, that indicates close relation with the factor. Thus, by referring to Pallant ${ }^{35}$, this finding is significant and consequently the 50 strategic knowledge, efficient behaviour and affective survey items in this analysis are accepted as valid for outdoor education survey items in this research.

Hence, it is hoped that this reconstructed questionnaire is of high quality and could have a high impact in evaluating the learning in Outdoor Education for the three components, namely strategic knowledge, behaviour efficiency, and affective; in addition to be widely used in Outdoor Education of Sabah secondary school camping activities.

A certain test instrument must be measured using several statistical methods so that the test instrument that was measured is consistent and reliable [35-37]. This is supported by Baumgartner and Chung who stated that an instrument which has construct validity is a valid and reliable instrument and could be used on any population that is being tested. Having formed 50 out of 100 outdoor education evaluation survey instrument that is valid and reliable, it could now provide the right and accurate information and feedback to the Sabah State Education Cocurricular Department in order to make improvement for whatever that is lacking currently and in the future. One of the common issues is the inability to provide accurate and correct feedback prior to the camping activity initiation. 
This study findings are consistent with those of D'Amato and Krasny and Thapa that demonstrated how students who have participated in Outdoor Education showed positive changes post assessment. The conducted activities were found to help the students to comprehend Outdoor Education better from the aspects of skills, knowledge, and societal values. This result was also supported by the studies of Sibthorp and Jostad and Gordon, who demonstrated a significant improvement among students who participated in Outdoor Education, since the students were highly interested in fun activities. Besides, the students learned novel knowledge while gaining experience and applied it in their school learning. Outdoor Education also conveyed positive implications towards learning and motor skills, knowledge in Outdoor Learning, and affective values that could be applied in school. This demonstrated that a built instrument could aid the identification of the weaknesses and the strengths of a participant while engaging a camping activity; where the weaknesses can be addressed rapidly and consequently help each participant to find and manifest their hidden potentials, which could simultaneously create future leaders [43-45].

\section{Conclusion}

Based on the study of Outdoor Education Instrument Validity and Reliability done by the researchers, it was found that each item developed with the statistical factor analysis method was valid and reliable. Out of the 100 items constructed, a total of 50 items were obtained via the factor analysis statistical method. The developed questionnaire was retested based on construct validity to ensure the item's validity and reliability. It is hoped that this reconstructed questionnaire is of high quality and could have a high impact in evaluating the learning in Outdoor Education for the three components, namely strategic knowledge, behaviour efficiency, and affective; in addition to be widely used in Outdoor Education of Sabah secondary school camping activities.

\section{References}

[1] Beames, S., Higgins, P. \& Nicol, R. Learning outside the classroom. abingdon: Routledge; 2011.

[2] Berry, M. 'Learning and teaching in adventure education' in berry, m., and hodgson, c. (eds.) adventure education. Abingdon: Routledge; 2011.

[3] Md Amin bin Md Taff. Learning methods in outdoor adventure education. Unpublished paper presented at UPSI Outdoor Education Instructor Workshop. 9-20th May 2007, Pulau Redang Malaysia;2007. Available from: http://www.freewebs.com/outdoora sia//microsoft - learning methods in outdoor adventure education.pdf

[4] Ford, P. Outdoor education: definition and philosophy. The American Alliance For Health, Physical Education, Recreation And Dance; 1986.

[5] Md Amin bin Md Taff. Pendidikan luar: Definisi dan perkembangan. tanjong malim: badan fasilitator pendidikan luar universiti pendidikan sultan idris; 2005. Available from: http://www.freewebs.com/outdoorasia/pendidikan luar, definisi dan perkembangan.pdf

[6] Laporan tahunan pusat kokurikulum Negeri Sabah; 2012.

[7] Gardner, J. N. Assessment and learning. J. Gardner (Ed.). Sage; 2012.

[8] Ahmad Hashim. Pengukuran kecergasaan motor. Tanjong Malim: Quantum; 2004.

[9] Baumgatner, T. A., \& H.Chung. Confidence limits for intraclass reliability coefficients. Measurement in Physical Education and Exercise Science 5: 2001; 179-188. 
[10] Gardner, H. Intelligence reframed: Multiple intelligences for the 21st century. Basic Books; 1999.

[11] Trochim, W. M. The research methods knowledge base, 2nd Edition; 2006. Available from: <http://www.socialresearchmethods.net/kb/>

[12] Bhattachharjee, A., \& Deb, S. Effect of gender and duration of illness on self esteem and emotional control of depressive patients. Journal of Psychosocial Research; 2011; 6 (2): 275-280. Available from http://search.proquest.com/docview/9265

87435 ?accountid $=13155$

[13] Muhamad, T. A., Sattari, H., \& Abadi, F. H. Effects of swimming on self-esteem among female college students. Asian Social Science; 2013; 9(16): 74.

[14] Vogler, J. W. Self-actualization and peak experiences in outdoor recreation. (Order No. 1518386, Clemson University. ProQuest Dissertations and Theses,65; 2012. Available from http://search.proquest.com/docview/1039261903?aacountid=13155(1039261903).

[15] Lee, K., \& Ewert, A. Adventure programs and diverse family styles. Journal of Experiental Education; 2013; 36(2):123-138. doi:10.1177/1053825913487886

[16] Kalargyrou, V., Pescosolido, A. T., \& Kalargiros, E. A. Leadership skills in management education. Academy of Educational Leadership Journal; 2012; 16(4): 39-63. Availablefromhttp://search.proquest.com/docview/1037802790?accountid=13155 kinanthropology/, 18(1).

[17] Potter, T. G., Socha, T. L., \& O'Connell, T. SOutdoor adventure education (OAE) in higher education: characteristics of successful university degree programmes. Journal of Adventure Education \& Outdoor Learning; 2012; 12(2): 99-119.

[18] Campbell, D. \& Stanley, J. Experimental and quasi ekeperimental designs for research. chicago: McNally College Publishing Co;1963.

[19] Nurul Ezzati Azizi. Hubungan antara konsep kendiri, dimensi personality dan persekitaran keluarga terhadap pencapaian akademik pelajar spa, spe dan spj. Tesis sarjana yang tidak diterbitkan. Universiti Teknologi $\quad$ Mara; 2008. Available from http://eprints.utm.my/cgi/search/simple?q=Nurul+Ezzati++Azizi.+\%282008\%29.+Hubungan+antar a+konsep+kendiri $\% 2 \mathrm{C}+$ dimensi+personality+dan+persekitaran+keluarga+terhadap+pencapaian+a kademik+pelajar+spa\%2C+spe+dan+spj

[20] Mohd Fitri Zamri. Gaya kepimpinan dan hubungannya dengan komitmen organisasi di pengkalan polis marin batu uban pulau pinang. Tesis sarjana muda yang tidak diterbitkan. Universiti Pertahanan Nasional;2013.

[21] Mohd Isnizam Bin Mohamad. Motivasi penglibatan pemain bola sepak sekolah sukan berprestasi tinggi dinegeri selangor. Tesis sarjana yang tidak diterbitkan. Universiti Pendidikan Sultan Idris; 2011.

[22] Modul program pembangunan sahsiah diri dan disiplin murid Bahagian pengurusan sekolah harian. Kementerian Pelajaran Malaysia; 2012.

[23] Kementerian Kesihatan Malaysia. Kajian pengamalan nilai-nilai murni oleh anggota di hospital kementerian kesihatan (kkm); 2006. Retrieved from: www.ihm.moh.gov.my/kmc/.../NilaiNilai\%20Murni.

[24] Manual pendidikan luar pusat kokurikulum negeri sabah. Pusat kokurikulum Malanggang Negeri Sabah Kiulu Tamparuli. manual yang tidak diterbitkan. Pusat Kokurikulum Negeri Sabah; 2012.

[25] Pallant, J. SPSS survival manual (2nd edI). NewYork, NY: McGraw-Hill; 2005.

[26] Tabachnick, B. G., \& Fidell, L. S. Biometrika table for statisticians 1 (2nd ed.) New York : Cambrigde University Press; 1996.

[27] Tabachnick, B. G., \& Fidell, L. S. Using multivariate statistics (5th ed.). Bosrom: Pearson Educational, Inc; 2007.

[28] Cohen, J. Statistical Power Analysis for the Behavioral Sciences. (2nd ed.). New Jersey: Lawrence Erlbaum Associates; 1988. ISBN 0-8058-0283-5.

[29] Cohen, J. A power primer. Psychological bulletin; 1992; 112(1): 155.

[30] Ary, D., Jacobs, L. C., \& Razavieh, A. Introduction to research in education (6th ed). Belmont, CA: Wadsworth/Thomson Learning; 2002. 
[31] Mohd Majid Konting Kaedah penyelidikan pendidikan. Kuala Lumpur: Dewan Bahasa dan Pustaka; 1994.

[32] Sidek Mohd Noah \& Jamaludin Ahmad. Pembinaan modul. Bagaimana membina modul latihan dan modul akademik. Selangor: Penerbit Universiti Pertanian Malaysia; 2005.

[33] Tuckman, B. W., \& Waheed, M. A. Evaluation an individualized science programme for community college students. Journal of Research in Science Teaching; 1981; 18: 489-495.

[34] Brown, T. A.. Confirmatory factor analysis for applied research. Guilford Press; 2012

[35] Pallant, J. SPSS survival manual (2nd edI). NewYork, NY: McGraw-Hill. 2001.

[36] Rosen, B. L. Understanding statistics in health science: Exploratory factor analysis extraction methods. Health Education Monograph Series; 2013; 30(2): 34-40.

[37] Powell, R. B., Stern, M. J., Krohn, B. D., \& Ardoin, N. Development and validation of scales to measure environmental responsibility, character development, and attitudes toward school. Environmental Education Research; 2011; 17(1): 91-111.

[38] Baumgatner, T. A., \& H.Chung. Confidence limits for intraclass reliability coefficients. Measurement in Physical Education and Exercise Science; 2001; 5: 179-188.

[39] D'Amato, L. G., \& Krasny, M. E. Outdoor adventure education: Applying transformative learning theory to understanding instrumental learning and personal growth in environmental education. The Journal of Environmental Education; 2011; 42(4): 237-254.

[40] Thapa, B. The mediation effect of outdoor recreation participation on environmental attitudebehavior correspondence. The Journal of Environmental Education;2010;41(3):133-150. Available from http://search.proquest.com/docview/744220681? accountid=13155

[41] Sibthorp, J., \& Jostad, J. The social system in outdoor adventure education programs. Journal Of Experiential Education;2014; 37(1):60-74. doi:10.1177/1053825913518897

[42] Gordon, L. Outdoor education opportunities for middle school students: academic and social impacts of adventure programs. Online Submission;2011.

[43] Fiskum, T. A., \& Jacobsen, K. Outdoor education gives fewer demands for action regulation and an increased variability of affordances. Journal of Adventure Education \& Outdoor Learning; 2012; 1 24.

[44] Lien, M., \& Goldenberg, M. (2012). Outcomes of a college wilderness orientation program. Journal Of Experiential Education, 35(1), 253-271.

[45] McCann, A. E. The cultivation and transfer of life skills through the outdoor education program at besant hill school ojai, CA. (Order No. 1510669, Prescott College). ProQuest Dissertations and Theses; 2012: $124 . \quad$ Available from http://search.proquest.com/docview/1021033836?accountid=13155. (1021033836) 